\title{
Extradition in Fascist Italy (1922-1943) and in Brazil of Getúlio Vargas (1930-1945) between the Ascension of "Fascism Criminal Law" and the Survival of the Liberal Tradition of Criminal Law ${ }^{1}$
}

\author{
Extradição na Itália Fascista (1922-1943) e no Brasil de Getúlio Vargas (1930- \\ 1945) entre a Ascensão do "Direito Penal do Fascismo" e a Sobrevivência da
} Tradição Liberal do Direito Penal

\author{
Diego Nunes ${ }^{1}$ \\ ${ }^{1}$ Universidade Federal de Santa Catarina, Florianópolis, SC, Brasil
}

\begin{abstract}
This paper aims to present the legal treatment given to extradition in Fascist Italy and in the Brazil of Getúlio Vargas to understand if the institute has suffered authoritarian torsions both on the field of domestic Law and on the diplomatic relations between these countries. On the Codice Rocco, the provision on extradition was meant to strengthen the repression. On its turn, if on one side the 1938 Brazilian Extradition Act relies on the elements of the institute created in the nineteenth century, it also adds important elements to the defence of a strong State. However, the Italian-Brazilian extradition treaty of 1932 attached to the liberal paradigm ended up protecting the individuals subjected to extradition. Thus, were these rules truly of a fascist origin? The hypothesis is to realize that the "Fascism Criminal Law" is not quite a revolution, since despite introducing major changes it cohabits with the liberal tradition of Criminal Law.
\end{abstract}

Keywords: Extradition. International Treaties. Authoritarianism.
Resumo: O presente artigo tem como objetivo apresentar o tratamento jurídico dado à extradição na Itália Fascista e no Brasil de Getúlio Vargas para compreender se o instituto sofreu torsões autoritárias, seja no campo do direito interno como nas relações diplomáticas entre os dois países. No Codice Rocco, as regras sobre extradição foram pensadas para fortalecer a repressão. Por sua vez, se de um lado a lei brasileira de extradição de 1938 retomava elementos do instituto quando criado no século XIX, também adicionou importantes elementos para a defesa de um Estado forte. Porém, o tratado Itálo-Brasileiro de extradição de 1932 aproximou-se do paradigma liberal, resultando em proteção aos indivíduos sujeitos à extradição. Assim, tais regras teriam realmente uma origem fascista? A hipótese é a perceber que o "Direito Penal fascista" não foi exatamente uma revolução, já que apesar de introduzir alterações importantes, coabitou com a tradição liberal de Direito Penal.

Palavras-chave: Extradição. Tratados Internacionais. Autoritarismo.

${ }^{1}$ This text has already been published in Forun Historiae Iuris, available in: https:// forhistiur.de/media/zeitschrift/Nunes_-_1-fo_YiMiB9W.pdf.

Recebido em: 30/10/2018

Revisado em: 21/11/2018

Aprovado em: 28/11/2018 


\section{Introduction}

Extradition is an act of cooperation, which is performed between sovereign States at the request of one of them, turning in accused or convicted person of a crime to be prosecuted or to serve an already imposed sentence. ${ }^{2}$ As put by Emanuele Carnevale, the late nineteenth century and early twentieth century are marked by a quest for greater collaboration in the area of common international legal assistance against crime, no matter where it happened and where they found the suspects and/or indictees of such actions:

Noi siamo in tempo piuttosto di collaborazione, che evidentemente è una cosa diversa di azione: la prima rappresenta sempre un agire distinto, per quanto associato e coordinato; la seconda, invece, è un tutto unico, è l'apice del movimento unitario, lo dico quindi azione perchè guardo principalmente alla fase finale, di cui considero la presente come preparatoria, qualunque sia il corso di anni di cui essa abbia bisogno; e intanto anche per l'oggi la parola può accogliersi, intendendola in senso largo e non stretamente preciso ${ }^{3}$.

This work will examine the extradition treaty between Brazil and Italy in 1932 and the domestic legislation of each country on extradition from the current criminal-legal thought in that period. Brazil had issued a special law on the subject; Italy, on the other hand, left the matter to be regulated by provisions in the Criminal Code ${ }^{4}$. The goal is to see

\footnotetext{
${ }^{2}$ A complete synthesis about the conceptions in that period, also included the comparative prospective, can be found in Antonio Bento de Faria, Código Penal brasileiro (comentado): noções gerais, interpretação da lei penal, extradição (Decreto-Lei n. 2.848, de 7 de dezembro de 1940) vol 5 (2nd edn Record 1958) 87-8. He was also a Brazilian Supreme Court's Justice.

${ }^{3}$ Emanuele Carnevale, 'Linee unitarie dell'azione internazionale contro il delitto' (1933) 4 Rivista penale, 873.

${ }^{4}$ However, that's not means the Italian doctrine don't wish a specific regulamentation about this: 'Il codice penale attualmente in Italia segna, anche in linea di estradizione, um grande progresso sulle legislazioni che lo hanno preceduto [...] Queste poche statuizioni non bastano evidentemente a regolare una materia che presenta casi molteplici, e questioni oltremodo difficili. Cosicchè, quando si tratta di concedere una estradizione, bisogna
} 
how these laws and the treaty between Italy and Brazil are composed in regards to the maintenance of the liberal tradition of the nineteenth century or to the rising authoritarianism experienced by both countries with Mussolini and Vargas in the first half of the twentieth century and their doctrinal term.

The relationship between treaty and domestic law is dialectical, because at the same time that the already present domestic legislation determines the treating possibilities, ${ }^{5}$ the international concerts directly influence changes in the extradition law by possessing the dynamics of international practice into a particular order, influencing the legislator's new choices.

In this sense, criminal doctrine is a privileged locus to the extent that it builds a specific scenario on the theme, reflecting or moving away from criminal policy choices of each State. There is already historiography on the analysis of authoritarian inflows about Criminal Law ${ }^{6}$. Extradition has a double valence here, due to reflections within internal and external law. It is interesting to note how the presentation of a new discourse of authoritarian hue or the maintenance of a traditional liberal discourse behaves in this particular institute.

Authoritarianism presented itself after World War I as a front-line alternative to the liberal model in the context of a world crisis. In the 1930s, Fascism found itself bound in Italy, moving to an 'Italian road to totalitarianism'. ${ }^{7}$ Brazil, in turn, experienced a period of uncertainty, since it had recently surpassed the Revolution of 1930, ruled by a provisional

necessariamente ricorrere al trattato che lega nostro governo allo Stato richiedente e qualora il trattato manchi o taccia, l'autorità giudiziaria nel prendere la sua deliberazione non è vincolata da alcuna norma positiva' Costantino Castori, 'Necessità di una legge speciale che regoli la estradizione' in Per onoranza di Francesco Carrara: studi giuridici (Tipografia Editrice Alberto Marchi 1899) 19.

${ }^{5}$ Ugo Aloisi, 'Estradizione' in Mariano D'Amelio (ed), Nuovo digesto italiano vol 5 (UTET 1938) 689.

${ }^{6}$ See for all Mario Sbriccoli, 'Le mani nella pasta e gli occhi al cielo: la penalistica italiana negli anni del fascismo' in 28 QF (1999)

7 Pietro Costa, 'Lo "Stato totalitario": un campo semantico nella giuspubblicistica del fascismo' 28 Quaderni Fiorentini per la storia de pensiero giuridico (1999) 61. 
government that foreshadowed the future dictatorship claims of Getúlio Vargas that would take place in 1937.

A turnaround in the legal-criminal area was experienced. Fascism takes hold of Criminal Law as a regime's legitimizing discourse by the authority of imposing a strict legislation. The criminalists of the period, led by Arturo Rocco ${ }^{8}$ and Vincenzo Manzini ${ }^{9}$ consolidate the legal technical approach that closes its eyes to the civil commitment of jurists from the previous period to keep against the role of interpreting the Law, regardless of its nature, when they did not place themselves directly on defence of Fascism $^{10}$.

In Brazil, there is a clear succession of generations, where the imported and artificial debate between the classical and positive schools and the criminal concern in building a truly national criminal science starts to lag behind. Nevertheless, the response to the previous movement is very similar to the Italian one: Brazilian Criminal Law surrenders to the dogmatic paradigm of technical legal nature, in that criminal science is reduced to the study of the criminal law in force. The figure par excellence is Nélson Hungria, which in these early years of 1930 launches several studies in that direction. ${ }^{11}$

\footnotetext{
${ }^{8}$ Alfredo Rocco's brother, Italian jurist of indirizzo tecnico giuridico of Criminal Law. See Arturo Rocco, Opere giuridiche, 3 voll., Roma 1932-1933. See also Mario Sbriccoli, La penalistica civile. Teorie e ideologie del diritto penale nell'Italia unita, originariamente in Aldo Schiavone (a cura di), Stato e cultura giuridica in Italia dall'Unita 'alla Repubblica, Roma-Bari, Laterza, 1990, pp. 147-232.

${ }^{9}$ Eminent jurist addept of technical approach, with so many works on Criminal Law, specially your famous Trattato di diritto penale (here Torino, 1933). See also Mario Sbriccoli, Dissenso politico e diritto penale in Italia tra Otto e Novecento. Il problema dei reati politici dal 'Programma' di Carrara al 'Trattato' di Manzini, « Quaderni fiorentini per la storia del pensiero giuridico moderno », II, 1973, pp. 607-702.

${ }^{10}$ Sbriccoli (n. 5), p. 817.

${ }^{11}$ Most important Brazilian jurist of technical approach of Criminal Law. He was also a Brazilian Supreme Court's Justice. See Nélson Hungria [Hofbauer], Comentários ao código penal (here Rio de Janeiro, 1958). See also Ricardo Sontag, Código e Técnica. A reforma penal brasileira de 1940: tecnicização da legislação e atitude técnica diante da lei em Nelson Hungria (UFSC 2009).
} 
This work aims to analyze the standards (treaty and domestic law) relating to the Italian-Brazilian case, paying special attention to the discussion about the possibility of extradition of political criminals.

\section{The 1932 Treaty and the Domestic Legislation Between Liberal Tradition and the Rising Authoritarianism}

Even before the rise of Vargas, but already under Fascism, Brazil and Italy began negotiations for the making of their second extradition treaty, which was to be completed after the 1930 Revolution $^{12}$. Henceforth, Brazilian law and the sparse Italian provisions would rule only on the present gaps in the recently struck agreement.

At that time, the new Italian Criminal Code of 1930 was already in force. Extradition regulated in Article 13 served a double discourse. Externally, it aimed to put Italy in the forefront of an early international collaboration to fight crime $^{13}$, to the extent that it bore the maximum application speech of the institute by reducing exceptions to turn-ins ${ }^{14}$.

12 '9. - Entaboladas negociações, conseguiram os dois Estados, ao cabo de longos annos, chegar, afinal, a uma formula de tratado, quando, ao terminar o periodo administrativo, que precedeu o do Governo Provisório, forma suspensas as conversações a respeito [...] 11. - O Tratado em apreço é o primeiro que o Brasil celebra com um paiz não americano, e matéria de extardição, depois de promulgada a Lei n. 2.416, de 28 de Junho de 1911' Afrânio de Mello Franco, 'O tratado de extradição do Brasil com a Itália: a exposição de motivos apresentada ao Chefe do Governo Provisório pelo Sr. Dr. Afrânio de Mello Franco, Ministro da Relações Exteriores' in 33 Archivo Judiciário (1932) 13.

13 'Si, par contre, comme on l'a souvent affirmé, l'extradition doit être considérée comme un acte de solidarité humaine, les restrictions que nous venons de mentionner ne se justifient nullement [...] L'un en extradant, l'autre en jugeant, punissant, reclassant, ils ne font que servir une cause commune, qui est celle de la défense internationale contre le crime. Un regard sur les lois et traités existants suffit à nous convaincre que le monde actuel est encore bien loin de pouvoir tirer toutes les conséquences de ces vérités primordiales. Si nous croyons devoir rappeler, ce n'est pas pour critiquer des textes où des réserves, imposées par les circonstances, atténuant la rigueur des principes. Nous n'avons d'autre but que de mettre en lumière la difficulté de la tâche qu'assument les Conférences internationales pour l'unification du droit pénal" Henry G. J. Maas Geesteranus, 'Les résultats de la quatrième conférence internationale pour l'unification du droit pénal' in 38 La Giustizia penale (1932) 21.

14 'I nuovi codici hanno disciplinato l'istituto della estradizione in conformità dei principî elaborati dalla scienza, accolti nei trattati e nelle consuetudini e sanciti dalla giurisprudenza 
It thus ended any distrust regarding foreign justice effectiveness ${ }^{15}$, because there would not even be a need for a turning in treaty ${ }^{16}$.

Domestically, however, such position met the proposed intensification of criminal law, a symbol of state authority, as so often hypothesized by Minister Alfredo Rocco, as by the doctrine affiliated to Fascism. In this sense we celebrate the supposed possibility of extradition of political offenders, the main target of this new conception of Criminal Law.

From the content of the treaty, the promise of the Brazilian Plenipotentiary Foreign Minister to the concert was about respect for the traditions, because "molded on more liberal principles and broader legal culture of our day, it constitutes a complementary to the series of approaching acts previously signed between the two countries"17.

The Explanatory Memorandum gives great prominence, for example, to the principle of extradition of nationals, which until now appeared as a breakthrough in the nations' concert, being Brazil the first country to set such treaty with Italy, which recently allowed such a situation with novel coding ${ }^{18}$. In the case of extradition of nationals, Fascism and the Estado Novo took inverse directions. The possibility of extradition of nationals inserted by Article 13 of the new Italian Criminal Code was seen by the doctrine, as well as in the issue of political crime,

dei paesi più civili [...] L'Italia tiene il primo posto sia per le tradizioni storiche, sia per l'opera dei giuristi a cominciare dal fitto medioevo sino a Cesare Beccaria, a Pasquale Stanislao Mancini, ad Enrico Ferri, onde furono fermati i quattro cannoni fondamentali regolatori della consegna del reo' Salvatore Adinolfi, 'La estradizione ed i nuovi codici penali italiani' in 38 GP (1932) 1.

15 'Il codice vigente ha, inoltre, sprezato la tradizione ed il principio del divieto dell'estradizione del cittadino. Nel proclamarlo il codice Zanardelli si metteva, in conformità dei tempi, nel solco della generale diffidenza dello Stato verso la giustizia di un Stato straniero [...]' Alfredo De Marsico, Diritto penale: parte generale (Jovene 1935) 87.

1699 RP (1925) 272.

${ }^{17}$ Franco (n 8) 13.

${ }^{18}$ Ibid 15-21. 
as an avant-garde action of the regime under international collaboration ${ }^{19}$. There would be no fear, because it was conditioned to the existence of a treaty, not merely in need of a declaration of reciprocity, and even in case of suspicion, the administrative licensing system would have further protection $^{20}$.

Among the treaties that would work under such logic, the first that Italy would subscribe to that effect was exactly in Brazil ${ }^{21}$. At the time, the constitution of 1891 and the law of 1911 allowed Brazil to such agreement. Putting oneself at international level as countries that gave an effective contribution to combating crime was a big motivation ${ }^{22}$.

19 'Rilevi particolari. 1o) La estradizione deve di regola applicarsi per tutti i delitti. Le eccezioni debbono contemplarsi nelle convenzioni e nelle leggi interne, ed è preferibile che tali eccezioni si precisino non mediante il nomen iuris, ma per la quantità e la specie delle pene [...] 6o) La estradizione del cittadino non è consentita se non sia concessa per convenzione. I più eminenti scrittori - da Bernard a Fauchille, da Holzendorf a Bluntschly, da Pessina a Fiore, da Garofalo a Longhi - invocavano la soppressione del divieto [di estradizione dei cittadini] in conformità del voto espresso nel congresso di Oxford [...] Pertanto la nuova disposizione legislativa merita la maggiore lode' Adinolfi (n 10) 14; 'Condizioni dell'estradizione - la quale è regolata dalla legge penale italiana, dalle convenzioni, e dagli usi internazionali - sono (art. 13): ... $3^{\circ}$ ) che l'estradando non sia cittadino italiano, salvo che l'estradizione non sia espressamente consentita nelle convenzioni internazionali. Qui è riprodotto il divieto del codice passato, ma non in via assoluta, come in quello, perchè si ammette che pattuizioni espresse internazionali possano intervenire. Per tal modo è agevolata la via ad eliminare, con meditata cautela, uno dei più vecchi e forti ostacoli alla ammissibilità dell'estradizione, che non dipendeva da ragioni scientifiche, ma da diffidenze politiche' Giuseppe Maggiore, Principi di diritto penale (Zanichelli 1932) 120-1.

20 'Notevole anche la disposizione del nuovo Codice (art. 13, ultimo capoverso), secondo cui la estradizione del cittadino non è ammessa, salvo che essa sia espressamente consentita nelle convenzioni internazionali. L'estradizione potrà essere domandata soltanto da quegli Stati, che saranno ritenuti dallo Stato italiano idonei a giudicare con le necessarie garanzie di giustizia; né ciò esclude la possibilità di rifiutare la estradizione in casi eccezionali, essendo dal nostro diritto interno riconosciuto al Governo un potere discrezionale in tal campo, anche quando esista trattato speciale e sia stato dall'Autorità giudiziaria manifestato parere favorevole all'estradizione' Eugenio Jannitti Piromalo, Corso di diritto criminale (Colombo 1932) 68-9.

${ }^{21}$ Manzini (n. 8), p. 420-421.

${ }^{22}$ In Italy: 'Per l'art. 9 del codice abrogato il Governo del Re poteva offrire o concedere l'estradizione di un delinquente nel concorso di tre condizioni: che l'estradando non fosse 
Respecting the current Brazilian law of 1911 and the open clause of Article 13 of the Italian code, as well as the tendency of extradition treaties from the early twentieth century, one leaves the exhaustive list model for a generic clause that kept the institute's job possible for all ordinary crimes (Article 2).

The exceptions contained in Article V, are the same ones that were already present in the national legislation. This excludes the possibility of extraditing "special" crimes, among which those committed by the press, politicians and the military (Article V, 5) $)^{23}$.

An interesting new feature was the inclusion of the impossibility of extradition if the crime in the requesting country is the jurisdiction of an exceptional court (Article 6, b). This article takes on importance to such an extent that in the time of entry into force of the treaty became active in Italy the Tribunale speciale per la difesa dello Stato, and that a few

cittadino italiano; che il delitto, pel quale l'estradizione fosse offerta o domandata, non costituisse un delitto politico po un altro reato a questo connesso; che dovesse precedere la deliberazione conforme dell'autorità giudiziaria del luogo, ove l'estradando si trovava. L'art. 13 ha posto nell'ultimo capoverso la prima la prima delle predette condizioni e cioè che l'estradando non sia cittadino italiano, mitigando però il divieto, nel senso che permette al Governo di estradare anche il cittadino, quando tale facoltà è espressamente consentita dalla convenzione di estradizione stipulata col paese nel quale il cittadino ha commesso il delitto. In tal modo il codice, orientandosi decisamente verso il sistema della legislazione inglese e di quella nord-americana, permette al Governo di assumere, mediante convezioni internazionali e quindi con sicurezza di piena reciprocità di diritti e di doveri da parte degli Stati contraenti un impegno di collaborazione internazionale sempre maggiore, nella lotta contro il delitto' Carlo Saltelli and Enrico Romano-Di Falco, Commento teorico-pratico del nuovo codice penale (UTET 1930) 117; in Brazil: 'Com sobejas razões tem-se impugnado, como injustificável, semelhante restrição, verdadeiro resquício do direito de asilo, incompatível de todo com os sentimentos de solidariedade internacional, cerceadora de procedimento eficaz contra os delinquentes' Galdino Siqueira, Tratado de Direito Penal: parte geral (José Konfino 1947) 216.

${ }_{23}$ 'Artigo V. Não será concedida a extradição [...] 5) por delitos políticos ou conexos com tais delitos, salvo si o fato incriminado constituir principalmente infração da lei penal comum. Neste caso, concedida a extradição, a entrega ficará dependente de compromisso, por parte do Estado requerente, de que o fim ou motivo político não concorrerá para agravar a penalidade. Qualquer apreciação sobre a natureza política dos fatos cabe exclusivamente ás autoridades do Estado requerido'. 
years later it would be Brazil to do such experiment with the Tribunal de Segurança Nacional.

Despite both courts having jurisdiction for the prosecution of political crimes, there could be discussion in the cases of application of the "Swiss" clause under the new treaty. Thus, with the possibility of extradition by the understanding that the offense was particularly common, the question would be if the courts could judge such crimes. Both courts were created as temporary agencies, but were made permanent. It would be strange for a country to consider exceptional a tribunal similar to that which it itself holds ${ }^{24}$.

From what investigated so far, there was no reference to the application of this clause from the treaty. On the one hand, we will see the expansion of the concept of political crimes in both jurisdictions with set limit on the external scope. On the other, there are studies that show a link within the police that would allow an underground action to the judicial means, typical of authoritarian regimes ${ }^{25}$.

${ }^{24}$ In this way, it is interesting the Bento de Faria's opinion: 'Que se deve entender por Tribunal ou Juízo de exceção? Evidentemente, são os criados fora da organização judiciária do Estado requerente, sem caráter de estabilidade, para julgamento de determinados casos, não apresentando as garantias da boa administração da justiça, pouco importando que na sua composição entrem Juízes do quadro da magistratura regular [...] Não se devem confundir, porém, a jurisdição de exceção com juízes ou tribunais especiais, aos quais incumbe, normalmente, como integrantes da organização judiciária, o processo e julgamento de certos fatos, v.g. o Tribunal de Segurança Nacional, hoje extinto' Faria (n 1) 160-1. How we can see infra, that is not the only Author's conflict than conception and reality.

25 'O estreitamento das relações fez até com que o jornal "O Globo" estampasse com grande destaque a denúncia de Maurício de Medeiros, de que haveria um cláusula secreta entre Brasil e Itália, onde o Brasil empenhava-se em expulsar sumariamente de seu próprio território, e a conselho da Itália, os italianos indicados pelo governo fascista. $\mathrm{Na}$ verdade, embora não haja qualquer evidência sobre a existência desta cláusula secreta, que visava a repressão política policial, o próprio tratado, firmado entre os dois países, em 28 de novembro de 1931, era visto como uma espécie de escândalo repressivo. As principais críticas recaiam sobre o Artigo IV, que previa a "extradição de seus próprios cidadãos" [...] Havia muita boa vontade das autoridades italianas em relação às brasileiras. Afinal, ambas comungavam o mesmo ódio aos comunistas' Elizabeth Cancelli, De uma 
The treaty also predicted the impossibility of extradition to the death penalty, allowed in Italy, unless commitment to conversion to imprisonment (Article 7, 2nd part). Even after an amendment to the 1937 Brazilian Constitution, such possibility was opened to the most serious political crimes and murderers. The Additional Protocol of 1937 dealt only with the impossibility of extradition of nationals, a necessary adjustment to the 1934 Constitution which had been maintained by the letter of 1937.

With the blow of November 10th 1937, Brazil turns to authoritarian means. Affirmed on the idea of nationalism, a discourse of marginalization from abroad which was reflected in the laws relating to extradition and deportation was created ${ }^{26}$.

The Decree-Law number 394 of April 28th 1938, sought to give new shape to extradition in Brazil. However, unlike the 1911 Law, it did not denounce treaties then in force, such as the Italian-Brazilian one of 1932 with the Additional Protocol of 1937. Their guidelines were used as additional tool in the omission of provisions about issues therein versed and indicated conditions for the establishment of new bilateral concerts.

The main emphasis of legislation was the regulation about the impossibility of extradition of nationals, definitely abandoning any possibility of cooperation as agreed with Italy in 1931. Brazil has pledged to punish the foreign agent in its own territory. The regulation was also highlighted on the impossibility of extradition of political offenders, as well as exceptions to this rule, although the warranty of non-extradition of political offenders, which appeared for the first time in 1934 Brazilian Constitution $^{27}$, was not repeated in the letter granted in 1937.

sociedade policiada a um Estado policial: o circuito de informações das polícias nos anos 30 (Fundação Perseu Abramo 2003) 13.

${ }^{26}$ Arno Dal Ri Jr., O Estado e seus inimigos: a repressão política na história do Direito Penal (Revan 2006).

27 'Art. 113 - A Constituição assegura a brasileiros e a estrangeiros residentes no País a inviolabilidade dos direitos concernentes à liberdade, à subsistência, à segurança individual e à propriedade, nos termos seguintes: [...] 31) Não será concedida a Estado estrangeiro extradição por crime político ou de opinião, nem, em caso algum, de brasileiro'. 


\section{The (Im)Possibility of Extradition Because of Political Crimes in the Authoritarianism Era}

Sore point in regards to extradition is the question of political crime. The changes that Brazil and Italy imposed in their domestic laws to such category in the 1930 s brought further discussion to the topic.

The change of concept of political crime, laid down in Article 8 of the new Italian code generated numerous discussions in the extraditional field. However, this construction that modifies assumptions of the previous code is a recurring theme in the legal-criminal thought of the time, because the international consensus, concerned about increased collaboration, tended to restrict the concept of political crimes ${ }^{28}$.

Considerable doctrine - generally enthusiastic to Fascism defended the thesis that Italy would have started to allow extradition of political crime, by having omitted in his Article $13^{29}$, the prohibition in Article 9 of the Zanardelli Code ${ }^{30}$. Saltelli and Di Falco emphasize that

28 'Ma la tendenza odierna dottrinale, in ogni modo, in relazione alla pratica degli Stati,
sembra accertabile nel senso di una dichiarazione delle eccezioni all'eccezione, non
lasciando più passare sotto il manto della delinquenza politica reati che veramente non
vi rientrano, onde vien meno la ragione dell'esclusione dell'estradizione' Ugo Conti,
'Estradizione e delinquenza politica' 106 RP (1927) 356 .
29 'Articolo 13. Estradizione. L'estradizione è regolata dalla legge penale italiana, dalle
convenzioni e dagli usi internazionali. L'estradizione non è ammessa, se il fatto che
forma oggetto della domanda di estradizione, non è preveduto come reato dalla legge
italiana e dalla legge straniera. L'estradizione può essere conceduta od offerta, anche
per reati non preveduti nelle convenzioni internazionali, purchè queste non ne facciano
espresso divieto. Non è ammessa l'estradizione del cittadino, salvo che sia espressamente
consentita nelle convenzioni internazionali'.
30 'I codici precedenti che la proibivano si ispiravano ad una ideologia che il nostro
Regime ha sorpassata e secondo la quale il delitto politico era considerato una violazione
di una norma attuale, e, ad un tempo, preparazione di un diritto futuro [...] Anche le
situazioni ideali, voi vedete, ed una di questa era lo stato della coscienza giuridica verso
il delitto politico, non rimangono com quelle storiche' De Marsico (n 11) 84 ; 'Nel nostro
diritto interno non esiste divieto di estradizione per i delitti politici, come, invece, era
sancito nell'art. 9 dell'abrogato codice. I trattati e le convenzioni possono contenere, e in
effetti, contengono, limitazioni, in proposito' Remo Pannain, Manuale di diritto penale
(La Corte di Assise 1942 ) 138; 'Non vi è alcun limite oltre quello indicato, circa la natura 


\section{this choice reflects the high disapproval the fascist State gives to political crimes deserving of severe punishment anywhere ${ }^{31}$.}

del fatto oggetto della richiesta di estradizione: quindi è possibile l'estradizione anche per reati politici. L'innovazione della legge italiana è conseguente alla nozione adottata del delitto politico in dipendenza di quella sullo Stato. Le difficoltà di attuazione della norma dati i trattati che diversamente stabilivano secondo le precedenti dottrine, non ne diminuiscono certo l'alto significato di affermazione di un principio d'ordine civile, per cui non è possibile ritenere che uno Stato costituisca asilo contro i sovvertitori di altro Stato e per cui si possa ritenere in via generale meno pericolosa delinquenza quella così detta politica, senza nessun esame della personalità del reo, unico criterio che in materia possa indirizzare a una equità di giudizio. Onde è che la nostra legge deve attuarsi anche contro il criminale politico con tutti i mezzi di difesa individualizzata secondo i principi di questo codice' Mario Manfredini, Manuale di diritto penale (Athaeneum 1931) 26; 'Non è stata riprodotta l'altra condizione del codice passato, cioè il divieto di estradizione per delitto politico o con questo connesso e che occorra una previa deliberazione dell'autorità giudiziaria del luogo dove l'estradando si trova. La nuova valutazione che il nuovo codice fa del delitto politico, a differenza delle altre legislazioni a tipo individualista, lo porta a considerare questo delitto con maggiore rigore e perciò ad escludere ogni forma di favore' Maggiore (n 15) 120-121.

31 'La condizione che non si tratti di reati politici o di reati che a questi siano connessi, era incompatibile con la concezione fascista dello Stato, secondo la quale, nel conflitto fra interessi dello Stato e interessi del cittadino, quelli dello Stato debbono in ogni caso prevalere. In conseguenza, il divieto di estradizione per reati politici non è stato riprodotto nell'articolo in esame. Come a suo tempo abbiamo visto, la nuova legislazione penale italiana ha affermato risolutamente il suo disfavore per il delitto politico o per il delitto comune commesso anche soltanto in parte per motivi politici, e quindi era inammissibile per il delitto politico qualsiasi norme di favore, come quella dell'art. 9 del codice abrogato' Saltelli and Di Falco (n 18) 118; And another ones: 'Il codice penale abrogato (art. 9, primo capoverso), non ammetteva la estradizione del straniero per delitti politici, né per reati che a questi fossero connessi [...] Il nuovo Codice repudia qualunque limitazione al riguardo, coerentemente alla severa concezione del delitto politico da esso accolta. La Relazione Ministeriale sul Progetto definitivo pone giustamente in rilievo la contraddizione flagrante delle consuete convenzioni di estradizioni, in cui il maggiore impegno è promesso per quanto riguarda l'assistenza giudiziaria internazionale in ordine ai delitti comuni' Jannitti Piromalo (n 16) 68-9; 'L'estradizione può essere in linea generale conceduta ed offerta anche per reati politici (art. 8), nessun divieto essendovi al riguardo nella legge penale italiana; ma se le convenzioni internazionali ne facciano espresso divieto, l'estradizione non è ammissibile. In tal caso, nella determinazione di reato politico si deve aver riguardo alla nozione che ne dà la legge italiana' Nino Levi, 'Titoli primo, secondo e terzo del libro primo', in Ugo Conti (ed), Il codice penale illustrato articolo per articolo, vol 1 (1934) $140-1$. 
Galdino Siqueira and Eduardo Espínola Filho accepted such a position in Brazili ${ }^{32}$. The latter was supported by a quote from Ugo Aloisi extracted from the article "Extradition" in the Nuovo Digesto Italiano, legal encyclopedia of wide circulation in the fascist period ${ }^{33}$. However, it seems that the Brazilian treatise did not looked to the text as a whole, because Aloisi himself, despite appearing to be in favor of the measure, highlights the humorous opposite effect that the definition of Article 8 produced on the external front ${ }^{34}$.

Fascism's concern in expanding the concept of political crime created a discrepancy in the effects between the internal and external plans. On the one hand it provided a greater possibility of punishment in Italy as it expanded the list of behaviors that could frame this particular category of offenses that had a particular court with an exception procedure ${ }^{35}$. On the other, the second part of Article 8 of Rocco

32 Siqueira (n 18) 219; Eduardo Espínola Filho, Código de processo penal brasileiro anotado. Vol 1 (first published 1954, Bookseller 2000) 193.

${ }^{33}$ In verbis: 'Pela inovação (que talvez mais exatamente possa se qualificar de verdadeira revolução a respeito dos principias unanimemente professados no passado), que realizou o Código Penal em vigor, parece termos chegados ao ponto terminal do ciclo de exceções, cuja evolução traçamos através das legislações dos vários países. $\mathrm{O}$ art. 13 não reproduz a proibição relativa aos crimes políticos, que se encontrava no art. 9 do Código revogado' Aloisi (n 4) 696 - the translation of the Brazilian author is faithful.

34 'A questa premessa è da aggiungere un'altra, quella cioè che anche in materia di estradizioni noi siamo vincolati dall'art. 8 dello stesso c. p., il quale dispone che "agli effetti della legge penale" è delitto politico ogni delitto che offende un interesse politico dello Stato, ovvero un diritto politico del cittadino; ed è considerato come delitto politico il delitto comune determinato, in tutto o in parte, da motivi politici. Il contratto, evidentemente esistente fra la nostra legislazione interna e le convenzioni internazionali, porta alla strana conseguenza: che disposizioni, come quelle ora riferite dell'art. 8, le quali secondo lo spirito dei nuovi tempi, furono dettate per irrogare ai delinquenti politici un trattamento penale di maggiore asprezza rispetto ai delinquenti comuni, possono tradursi, nella realtà, in altrettanti coefficienti di attenuazione' Ibid 697.

${ }^{35}$ Legge 25 novembre 1926, n. 2008. Provvedimenti per la difesa dello Stato (pubblicata nella Gazzetta ufficiale n. 281 del 6 dicembre 1926): 'Art. 7 [...] Nei procedimenti pei delitti preveduti dalla presente legge si applicano le norme del codice penale per l'esercito sulla procedura penale in tempo di guerra. tutte le facoltà spettanti, ai termini del detto codice, al comandante in capo, sono conferite al ministro per la guerra. Le sentenze del tribunale speciale non sono suscettibili di ricorso, né di alcun altro mezzo di impugnativa, 
Code $^{36}$ went against the principle of preponderance. Thus preventing international collaboration on the part of Italy, since setting the crime subjectively political it accepted the preponderance even if partially. In addition to Aloisi, such a current counted with Vincenzo Manzini ${ }^{37}$.

Moreover, Italy had not agreed to such a possibility in any treaty, rather the opposite, as in the case of the treaty between Italy and Brazil ${ }^{38}$. The treaty of 1931 would have placed the parties in a position of international consensus on the matter. In the words of Chancellor Afranio de Mello Franco, "it appears from the foregoing that the Extradition Treaty with Italy, even in the case of political crimes, followed our conventional law, where Brazil is part and it followed ancient traditions in the practice of the institute" 39 .

salva la revisione. I procedimenti pei delitti preveduti dalla presente legge, in corso al giorno della sua attuazione, sono devoluti, nello stato in cui si trovano, alla cognizione del tribunale speciale, di cui alla prima parte del presente articolo'.

36 'Articolo 8. Delitto politico commesso all'estero. Il cittadino o lo straniero, che commette in territorio estero un delitto politico non compreso tra quelli indicati nel n. 1 dell'articolo precedente, è punito secondo la legge italiana, a richiesta del Ministro della giustizia. Se si tratta di delitto punibile a querela della persona offesa, occorre, oltre tale richiesta, anche la querela. Agli effetti della legge penale, è delitto politico ogni delitto, che offende un interesse politico dello Stato, ovvero un diritto politico del cittadino. È altresì considerato delitto politico il delitto comune determinato, in tutto o in parte, da motivi politici'.

${ }^{37}$ 'Con ciò non si esclude che anche in altri reati possa esservi siffatta offesa e quindi il carattere politico obiettivo. Non sembra che questa nozione sia conveniente, almeno per ciò che concerne l'estradizione, perchè è manifesto che un fatto delittuoso, ancorchè attentante ad ordinamenti politici, può essere mezzo per conseguire un scopo meramente individuale, che con la politica nulla ha da fare. In secondo luogo "sono considerati" politici (soggettivamente politici) i delitti comuni "determinati, in tutto o in parte, da motivi politici". Qui i possibili inconvenienti sono ancora maggiori, sempre con riguardo all'estradizione, perchè basta il concorso di un qualunque motivo politico per qualificare come politico un reato che è in sè stesso comune, dando così motivo agli Stati di negarci l'estradizione' Manzini (n 17) 425.

${ }^{38}$ Ibid 423.

39 'Verifica-se do exposto que o Tratado de Extradição com a Itália, ainda no que se refere aos crimes políticos, seguiu a nossa lei, o direito convencional em que o Brasil é parte e antigas tradições nossas na prática do instituto' Franco (n 8) 32. 
In fact, it was signed keeping the protection to the political criminal, contrary to what had already been set in Italy, in avant-garde position in the external front, but reactionary position in the internal front. The extradition of a political criminal by Italy would restrict to the possibility of a promise of reciprocity grounded in a disobedience to mutual comparison between Articles 8 and $13^{40}$. Even with the only opening provided by the insertion of the Swiss clause in the treaty it did not convince Manzini, because the broad discretion afforded to the requested State would easily render the arrangement useless ${ }^{41}$.

The Brazilian Act of 1938, already inside the authoritarian spirit of national security laws and the Constitution of 1937, showed the possibilities of opening the impossibility of extradition of political offenders in the paragraphs of its Article $2 .^{\circ}, \S 2 .^{\circ}$ innovated by placing a series of political movements, if they acted with violence, to be excluded from the bounty of non-extradition.

40 'È inutile dire che la omissione intenzionale dell'art. 13 fece apparire il legislatore del 1930 come inovatore e, quasi, rivoluzionario. Ma la fretta di questa deduzione è evidente. Anche nel vigore del c.p. 1889 un trattato Internazionale avrebbe potuto obligare l'Italia ad estradarre per i delitti politici, non potento il codice penale, che è una semplice legge, sopprimere tale possibilità. Lo stesso deve dirsi per il c.p. 1930, mutatis mutandis [...] L'art 13 era dunque tutt'al più una manifestazione implicita di intenzione con riguardo ad eventuali trattative diplomatiche e niente altro di questo; ma come manifestazone di intenzione doveva considerarsi deplacé. In ogni modo la prassi diplomatica dello Stato italiano successiva al c.p. 1930, confermò pienamente il principio della non estradabilità per i reati politici come dimostrano le Convenzioni con [...] il Brasile del 28 novembre 1931 (art. 5)' Rolando Quadri, 'Estradizione: diritto Internazionale' in Enciclopedia del diritto (Giuffrè 1967) 38.

41 'Reati connessi a reati politici. - Questi reati non sono presi in considerazione del vigente codice penale (e però non sono considerati reati politici), bensì invece dalla maggior parte delle convenzioni d'estradizione, che li equiparano, date certe condizioni, ai reati politici. Le convenzioni italo-brasiliana del 1931 [...] ad es., escludono dall'estradizione i reati connessi a reati politici, "salvo che il fatto costituisca principalmente un reato comune", lasciando alle Autorità dello Stato richiesto ogni apprezzamento in proposito. Si è così stabilito un criterio di prevalenza assai vago e indeterminato' Manzini (n 17) 427. 
Bento de Faria understood that such crimes, by violating a universal feeling about the established order, deserved punishment anywhere ${ }^{42}$. Such argument is based on a doctrinal consensus on the subject since the anarchic attacks appeared in the late nineteenth century. The punishment, according to the author, would really be worthy if such movements have a political program and are accepted by some civilized nation ${ }^{43}$. It is interesting that by the end, the minister says that the only modification with respect to the previous law was the issue of extradition of nationals.

Importantly, unlike the Italian case, the whole discussion about the concept of political crimes is out of the new Brazilian Criminal Code of 1940. Such code left the political crimes to the exceptional legislation. That way, the political dissension would be criminally fought duplicating the 'legality level' 44 to the legal-criminal order. The material force of the legality principle was mitigated with the creation of exceptional laws to control the political dissent, the innovations on extradition of political crimes also included.

Nélson Hungria faced the subject on several occasions. An example is his of the National Security Act of 1935. He was disappointed about the

\footnotetext{
42 'Pouco importa que essas formas de delinqüência (anarquismo, niilismo, comunismo, socialismo ou as que lhes sejam equiparáveis com outras denominações), resultem do desenvolvimento de um programa qualificado como - político [...] Sendo tais criminosos universalmente perigosos, daí resulta para os Estados o dever de direito internacional - da prestação da maior assistência recíproca em persegui-los' Faria (n 1) 137.

43 'É certo que certa nação européia adota princípios subversivos das instituições sociais, como a abolição completa do direito de propriedade. Nem por isso, nos países como o nosso, a propagação de tal credo há de perder o aspecto de atentado contra a sociedade' Ibid 137-8.

44 'Entra così nell'ordinamento, frutto quasi di una ineluttabile fisiologia, un duplice livello di legalità [...] Il dualismo nelle regole e nelle pratiche repressive che si viene affermando non riguarda, peraltro, la sola tutela dell'ordine pubblico: non si tratta soltanto di giurisdizione contro amministrazione, di codice penale contro legge di pubblica sicurezza, di giudici da un lato (che amministrano il diritto) e polizia dall'altro (che tutela l'ordine e la sicurezza). Il duplice livello di legalità discerne i "galantuomini" dai "birbanti" destinandoli a differenti filières punitive, fa prevalere l'opportunità politica sulla regola giuridica, lo scopo sul diritto' in Mario Sbriccoli, 'Caratteri originari e tratti permanenti del sistema penale italiano (1860-1990)' in Luciano Violante (ed), Storia d'Italia: legge, diritto, giustizia - Annali 14 (Einaudi 1998) 139-141.
} 
new dispositions that clashed with the traditional rulings on the subject ${ }^{45}$. To justify this situation, he quoted Francesco Carrara's Programma di Diritto Criminale where it was explained how difficult it was to build a scientific construction of the subject ${ }^{46}$. In classical Carrara's words, "when politics enter by the door, justice runs away through the window ${ }^{47}$. According to the Italian jurist, if it was impossible to construct a philosophical Criminal Law on political crimes, one should focus on the positive Criminal Law, therefore Carrara himself took a stand regarding the legislative productions of the time. However, Hungria escaped from the thinkers of the penalistica civile ${ }^{48}$ approaching the criminal-legal technicality when exempted himself of judging the legislator's work, that did not make any distinction between communists, anarchists and other ways of political dissent ${ }^{49}$.

The result is that the main political crimes listed in the Brazilian national security laws and the Rocco Code, in other words, the crimes

${ }^{45}$ Nélson Hungria, 'A lei de segurança' (1935) September Revista dos Tribunais 318.

${ }^{46}$ Nélson Hungria, ‘A evolução do Direito Penal brasileiro’ (1943) July Revista Forense.

47 'Ingenuo, un tempo io credetti che la politica dei liberi reggimenti non fosse la politica dei despoti: ma le novelle esperienze mi hanno pur troppo mostrato che sempre e dovunque quando la politica entra dalla porta del tempio, la giustizia fugge impaurita dalla finestra per tornarsene al cielo' Francesco Carrara, Programma del corso di diritto criminale, Vol 7.(Fratelli Cammelli, 6th edn 1898) 674-5.

48 'Una caratteristica permanente dell'esperienza penalistica italiana sta dunque nella durevole centralità delle questioni penali nelle diverse fasi della vita politica del Paese. Ad essa si correla un tratto distintivo che riguarda la vocazione, per così dire, della scienza e della cultura giuridica penali, impegnate con un loro spirito peculiare, storicamente caratterizzato, intorno alle ragioni ed ai modi del proibire, del prevenire, del giudicare e del punire. Si tratta di quella specifica attitudine dei penalisti italiani [...] che ho gia` avuto modo di designare come penalistica civile' Sbriccoli (n 41) 145.

49 'Haja vista a nossa recente lei de segurança - dec. N. 38, de 4 de Abril de 1935 que, na defesa da ordem político-social entre nós dominante, não faz descrime algum entre os brutaes discípulos de Bacunine e o "olho de Moscou" ou o mystico sigma do integralismo indígena [...] Deixemos, porém, de lado o aspecto reaccionario do decreto numero 38, apadrinado, aliás, pela Constituição de 16 de julho, para o apreciarmos como parte integrante do nosso direito constituído, que é o que é, e não o que devia ser' Hungria (n 41) 312 . 
of attempted subversion of the order ${ }^{50}$, cease to be political offenses for extradition if practiced by members of these political movements. We have here an effective nonsense, because Article $\mathrm{V}$ of the treaty designated the requested State as the competent authority.

Given the content of Article 8 of the Italian Criminal Code and conceptual layouts of successive national security laws of Brazil ${ }^{51}$, in both cases of broad spectrum, such conduct would always be considered a political crime in the territory, to the extent that communism was the main opposition to authoritarian regimes then present in Brazil and Italy. No wonder that the main defendants of political processes before the courts of both countries were the leaders of the national Communist parties.

\footnotetext{
${ }^{50}$ Although the Vargas Era (1935-1945) these are not political crimes more often, because the difficulty of the legal framework and perpetration, compared with the propaganda crimes and associative ones, cfr. Diego Nunes, O percurso dos crimes politicos durante a Era Vargas (1935-1945): do Direito Penal político italiano ao Direito da Segurança Nacional brasileiro (UFSC 2010) 150-184. However, they are the most serious crimes because once accomplished would change the political order would cause a revolution, and the accused would not be criminals, but victorious.

${ }^{51}$ The first National Security Act (Lei n. 38/1935) concepts came as complements to the crime of subversive propaganda in Article 22, but ended up becoming general: 'Art. 22. Não será tolerada a propaganda de guerra ou de processos violentes para subverter a ordem politica ou social (Const., art. 113, n. 9). $\S 1^{\circ}$ A ordem política, a que se refere este artigo, é a que resulta da independencia, soberania e integridade territorial da União, bem como da organização e actividade dos poderes politicos, estabelecidas na Constituição da Republica, nas dos Estados e nas leis organicas respectivas. $\S 2^{\circ}$ A ordem social é a estabelecida pela Constituição e pelas leis relativamente aos direitos e garantias individuaes e sua protecção civil e penal; ao regimen jurídico da propriedade, da família e do trabalho; á organização e funccionamento dos serviços publicos e de utilidade geral; aos direitos e deveres das pessoas de direito publico para com os individuos e reciprocamente'. The concept remains virtually unchanged in Decreto-Lei n. 431/1938: 'Art. $1^{\circ}$ Serão punidos na forma desta lei os crimes contra a personalidade internacional do Estado; a ordem política, assim entendidos os praticados contra a estrutura e a segurança do Estado, e a ordem social, como tal considerada a estabelecida pela Constituição e pelas leis relativamente aos direitos e garantias individuais e sua proteção civil e penal, ao regime jurídico da propriedade, da família e do trabalho, à organização e ao funcionamento dos serviços públicos e de utilidade geral, aos direitos e deveres das pessoas de direito público para com os indivíduos, e reciprocamente'.
} 
Even if restricting the interpretation to anarchism, the situation worsened because the actions taken as a classical anarchist movement were punished in domestic law within the same laws that dealt with political crimes. Therefore, to Manzini, the expansion of the concept of political crime by Article 8 ended up considering acts of anarchism and terrorism as political crimes ${ }^{52}$.

\section{Conclusion}

The authoritarianism of Fascism reached the institute in the Criminal Code in 1930. If the original idea was the extinction of the clause, the concept of political crime prepared in the same code prevented its effectiveness, since the excessive internal amplitude was expressed as a restriction on international level. Moreover, there even were resistances that would prevent concerts from being performed without such a clause, of which the Italian-Brazilian treaty is exemplary.

The Brazilian Extradition Act of 1938 also brought authoritarian inflows. It aimed to achieve a certain communist movement, the enemy of the constitutional regime, as noted in the preamble to the Constitution of 1937. The expansion was intended to free the country of undesirable elements.

However, it was realized that such a search to the fullest extent of the Criminal Law, in the case of political crimes, came to create a paradox: the more repressive domestically, the less power on the external front. The Italian-Brazilian case turns out to be interesting. The inclusion of authoritarian elements in the internal legislation masked by a liberal vanguard position, possible only in the duality that extradition allows, does not achieve success internationally. In this arena, both countries end up taking more conservative positions.

\footnotetext{
52 'Per il vigente codice penale i delitti anarchici, o terroristici in genere, sono indubbiamente delitti politici. Qualche convenzione, peraltro, li esclude dal novero dei delitti politici, agli effetti dell'estradizione' Manzini (n 17) 432.
} 
Thus, there is no way to talk about a Fascism Criminal Law as a single block. It not only used the tenets of liberal tradition, but had to give way in order to remain active even at the time when it had greater support.

\section{References}

ALOISI, Ugo. Estradizione' in Mariano D'Amelio. (Ed). Nuovo digesto italiano, [S.l.], v. 5, UTET, p. 689, 1938.

CANCELLI, Elizabeth. De uma sociedade policiada a um Estado policial: o circuito de informações das polícias nos anos 30. Fundação Perseu Abramo, 2003. p. 13.

CARNEVALE, Emanuele. Linee unitarie dell'azione internazionale contro il delitto Rivista Penale, p. 873, 1933.

CARRARA, Francesco. Programma del corso di diritto criminale, Fratelli Cammelli, 6th edn, [S.l.], v. 7, p. 674-675, 1898.

CASTORI, Costantino. Necessità di una legge speciale che regoli la estradizione in Per onoranza di Francesco Carrara: studi giuridici. Tipografia Editrice Alberto Marchi, 1899. p. 19.

COSTA, Pietro. Lo "Stato totalitario": un campo semantico nella giuspubblicistica del fascismo 28 Quaderni Fiorentini per la storia de pensiero giuridico, 1999. p. 61.

DAL RI JR., Arno. O Estado e seus inimigos: a repressão política na história do Direito Penal. Revan, 2006.

ESPÍNOLA FILHO, Eduardo, Código de processo penal brasileiro anotado. First published 1954, Bookseller, 2000. v. 1. p. 193.

FARIA, Antonio Bento de. Código Penal brasileiro (comentado): noções gerais, interpretação da lei penal, extradição (Decreto-Lei n. 2.848, de 7 de dezembro de 1940). 2nd edn. [S.l.]: Record, 1958. v. 5, p. 87-88.

HUNGRIA, Nélson, A lei de segurança Revista dos Tribunais, [S.l.], p. 318, September 1935 . 
HUNGRIA, Nélson, A evolução do Direito Penal brasileiro. Revista Forense, July, 1943.

HUNGRIA, Nélson [Hofbauer]. Comentários ao código penal. Rio de Janeiro: [s.n.] 1958.

MARSICO, Alfredo de. Diritto penale: parte generale, Jovene, 1935. p. 87.

QUADRI, Rolando. Estradizione: diritto Internazionale in Enciclopedia del diritto. Giuffrè, 1967. p. 38.

ROCCO, Arturo. Opere giuridiche, 3 voll., Roma 1932-1933.

SALTELLI, Carlo; ROMANO-DI FALCO, Enrico. Commento teoricopratico del nuovo codice penale. UTET, 1930. p. 117.

SBRICCOLI, Mario. Dissenso politico e diritto penale in Italia tra Otto e Novecento. Il problema dei reati politici dal 'Programma' di Carrara al 'Trattato' di Manzini, « Quaderni fiorentini per la storia del pensiero giuridico moderno », II, 1973. p. 607-702.

SBRICCOLI, Mario. La penalistica civile. Teorie e ideologie del diritto penale nell'Italia unita, originariamente in Aldo Schiavone (a cura di), Stato e cultura giuridica in Italia dall'Unita` alla Repubblica, Roma-Bari, Laterza, 1990. p. 147-232.

SBRICCOLI. Mario. Le mani nella pasta e gli occhi al cielo: la penalistica italiana negli anni del fascismo in 28 QF (1999).

SONTAG, Ricardo, Código e Técnica: A reforma penal brasileira de 1940: tecnicização da legislação e atitude técnica diante da lei em Nelson Hungria, UFSC, 2009.

Diego Nunes é Professor Adjunto I no Departamento de Direito e no Programa de Pós-Graduação em Direito do Centro de Ciências Jurídicas da Universidade Federal de Santa Catarina. Foi Professor Adjunto II na área de Fundamentos do Direito na Faculdade de Direito "Professor Jacy de Assis" da Universidade 
Federal de Uberlândia. Doutor em História do Direito pela Università degli Studi di Macerata (Itália). Mestre em Teoria, Filosofia e História do Direito pela Universidade Federal de Santa Catarina, possui graduação em Direito também pela Universidade Federal de Santa Catarina.

E-mail: diegonunes@ufu.br

Endereço profissional: Campus Universitário Reitor João David Ferreira Lima, s/n., Trindade, Florianópolis, SC. CEP: 88040-900. 